\title{
Review Article \\ Integrative Control of Energy Balance and Reproduction in Females
}

\author{
R. M. Garcia-Garcia \\ Physiology Department (Animal Physiology), Complutense University, Avenida Puerta de Hierro S/N, 28040 Madrid, Spain \\ Correspondence should be addressed to R. M. Garcia-Garcia, rosa.garcia@vet.ucm.es
}

Received 16 August 2012; Accepted 4 September 2012

Academic Editors: K.-P. Brüssow, J. F. Hocquette, and A. Shamay

Copyright ( $) 2012$ R. M. Garcia-Garcia. This is an open access article distributed under the Creative Commons Attribution License, which permits unrestricted use, distribution, and reproduction in any medium, provided the original work is properly cited.

There is a strong association between nutrition and reproduction. Chronic dietary energy deficits as well as energy surpluses can impair reproductive capacity. Metabolic status impacts reproductive function at systemic level, modulating the hypothalamic GnRH neuronal network and/or the pituitary gonadotropin secretion through several hormones and neuropeptides, and at the ovarian level, acting through the regulation of follicle growth and steroidogenesis by means of the growth hormone-IGF-insulin system and local ovarian mediators. In the past years, several hormones and neuropeptides have been emerging as important mediators between energy balance and reproduction. The present review goes over the main sites implicated in the control of energy balance linked to reproductive success and summarizes the most important metabolic and neuroendocrine signals that participate in reproductive events with special emphasis on the role of recently discovered neuroendocrine peptides. Also, a little overview about the effects of maternal nutrition, affecting offspring reproduction, has been presented.

\section{Introduction}

The relationship between energy balance and reproduction is well known. Nutrition has a significant impact on numerous reproductive functions including hormone production, folliculogenesis, fertilization, and early embryonic development [1-3]. This intimate association is because reproductive processes are energetically expensive, and the brain must temper the fertility of individuals to match nutritional availability $[4,5]$. Reproduction function in mammals can be inhibited when food availability is low or when increased energy demands are not met by compensatory food intake such as in short-term and chronic withdrawal of nutrients [6-8]. This very close alignment with the food supply is more important in females, where pregnancy and lactation are linked to considerable energetic expenses, needed for the nurture of embryos and newborns [9]. In fact, her reproductive outcome can be seriously altered and even life threatening to both the mother and offspring when nutritional imbalance occurs [4].

The link between nutrition and reproduction is mainly through the energy balance $[1,4]$, apart from the effect of specific nutrients that act independently of such energy balance [10]. Energy balance is usually measured as energy input, considered as feed intake, minus energy output that includes milk, maintenance, activity, growth, and pregnancy expenses $[9,11]$. In order to keep constant body energy stores, in mammals, a series of homeostatic events leading to maintenance of energy balance are activate when a state of energy scarcity or abundance occurs.

High yielding animal producers like high-producing dairy cows or primiparous rabbits are often in a serious negative energy balance (NEB) in some physiological phases, that is, lactation, since the net nutrient requirements are more elevated than the net nutrient intake in that stages (cows: $[12,13]$; rabbits: [14]). NEB provokes low reproductive performance. Most of the studies about the influence of NEB have been performed on bovine species. It is well known that the metabolic condition of cows in NEB shifts to catabolic metabolism, which in turn causes increased plasma growth hormone and nonesterified fatty acid concentrations and decreased plasma insulin-like growth factor-I, insulin, and glucose concentrations [15-17] as well as leptin serum concentrations [18]. Also, compromised metabolic status 
decreases preovulatory follicle function [19], by means of intrafollicular changes such as production of low estradiol concentrations and IGFBP $[20,21]$. This can be probably because cholesterol transport into the mitochondria to initiate steroidogenesis is affected [21]. In any case, changes in the growth pattern of the ovarian follicle during a period of NEB can indirectly affect oocyte quality that is ultimately responsible for the subfertility in dairy cows [22]. In other species with high requirements in early postpartum period like primiparous rabbit does, they show a profound NEB which negatively impacts on ovarian follicular and oocyte quality, giving rise to a poor reproductive performance too $[14,23]$.

In several species, long-term (chronic) and short-term (acute) undernutrition has been observed to suppress female reproduction through the suppression of GonadotrophinReleasing Hormone (GnRH) secretion, the delay of onset of puberty, the interference with normal estrous cycles, and the alteration of endocrine function (gilt: [24]; heifer: [25, 26]; ewe: [27]; rabbit: [28]). In this sense, inhibition or delay of preovulatory surge release of $\mathrm{LH}$, decrease of oestradiol-17 $\beta$ discharge $[1,29]$ and increase of serum progesterone concentrations [30] have been described. Also, undernutrition affects ovarian follicle development [31], ovulation [32], blastocyst formation [33], and fertility rates $[5,34]$.

In contrast, when the nutritional requirements are less than the food supply, the animal will store the excess of nutrients (glycogen, triglycerides), being in a positive energy balance status. However, reproductive abnormalities are also common in obese individuals although mechanism behind this effect is unclear. In the genesis of obesity-induced infertility, pituitary insulin signaling seems implicated $[35,36]$. Furthermore, recent advances in several species have been demonstrated that obesity negatively impacts the developmental competence of oocytes [37, 38]. Nevertheless, shortterm energy supply termed as "flushing" around conception can improve ovulation rate and litter size [39] mainly in small ruminants. Flushing enhances follicle recruitment and follicle growth (for review see [4]). However, a high level of feeding is only beneficial to oocytes from animals of low body condition, because it is detrimental to oocytes in animals of moderate-to-high body condition [40].

The mechanisms mediating the influence of metabolism and nutrition on fertility are currently unclear, but there is a strong association between metabolic disorders and infertility [41]. It is difficult to determine the specific functions and mechanisms by which nutrition influences reproductive function. Circulating factors and hypothalamic circuits coordinate these responses in a complex manner. It is well known that the effects of nutrition are either mediated directly through effects on hypothalamic GnRH or pituitary gonadotropin secretion or indirectly through the growth hormone-IGF-insulin system or local ovarian mediators [42]. In the past years, several hormones and neuropeptides have demonstrated their important role as local mediators of brain to arbitrate the link between energy balance and reproduction. Understanding the integrative control of energy balance and reproduction can lead to reproductive success that will have benefits to improve clinical outcomes and farm animal production systems. The present review goes over the main sites implicated in the control of energy balance linked to reproductive success and summarizes the most important metabolic signals that participate in reproductive events with special emphasis on the role of recent discovered neuroendocrine peptides. A little overview about the intergenerational effects of nutrition affecting offspring has been presented.

\section{Sites Implicated in the Control of Energy Balance Linked to Reproduction}

Circulating levels of nutrients and metabolites, frequently, are not directly related to any of the factors that determine their concentrations but are related to a physiologically relevant combination of factors including nutrient reserves, nutrient intakes and nutrient demands for maintenance, growth, or production [43]. An enormous selection of chemical messengers and metabolic processes is involved in maintenance of energy balance and reproductive processes [8]. Most of these factors influence the hypothalamicpituitary-gonadal (HPG) axis (for review see [8]). Potential sites of action of nutrition on ovarian function include systemic effects at the hypothalamic level via GnRH synthesis and release; the anterior pituitary through control of synthesis and release of FSH, LH, and growth hormone (GH); at the ovarian level through regulation of follicle growth [44] and steroid synthesis [45]. There are also possible local sites of action via effects on the cascade of growth factors and their binding proteins within the ovary $[42,45]$. See Figure 1.

\subsection{Hypothalamic-Pituitary Axis. A multilevel regulatory} activity of autonomic centers and neuronal pathways is a noteworthy characteristic of many hypothalamic structures. The same groups of neurons are simultaneously involved in the performance of many regulatory functions. They are responsible for maintenance of energetic and osmotic homeostasis and also involved in the central regulation of reproductive processes, including sexual maturation and mating behavior [46].

The brain uses adipose- and gut-derived hormones, such as leptin, insulin, and ghrelin, to modulate the activity of the GnRH neuronal network that drives reproduction [5]. Recent studies had revealed that the major mechanism whereby the metabolic status impacts reproductive function involves modulation of the GnRH neuronal network at the hypothalamus [5, 8, 47], mainly by the multiple hypothalamic peptidergic systems responsible for the homeostatic control of energy balance [48] (this topic is reviewed in the following). Besides, metabolic challenges modify the $\mathrm{GnRH}, \mathrm{LH}$, and FSH surge, independently of their effects on pulsatile LH secretion [49].

2.2. Ovary. The ovary can respond directly to metabolic inputs independently of gonadotropin drive [50]. One of the more important events modulated by energy balance is folliculogenesis. The ovarian follicle is an integral part of 


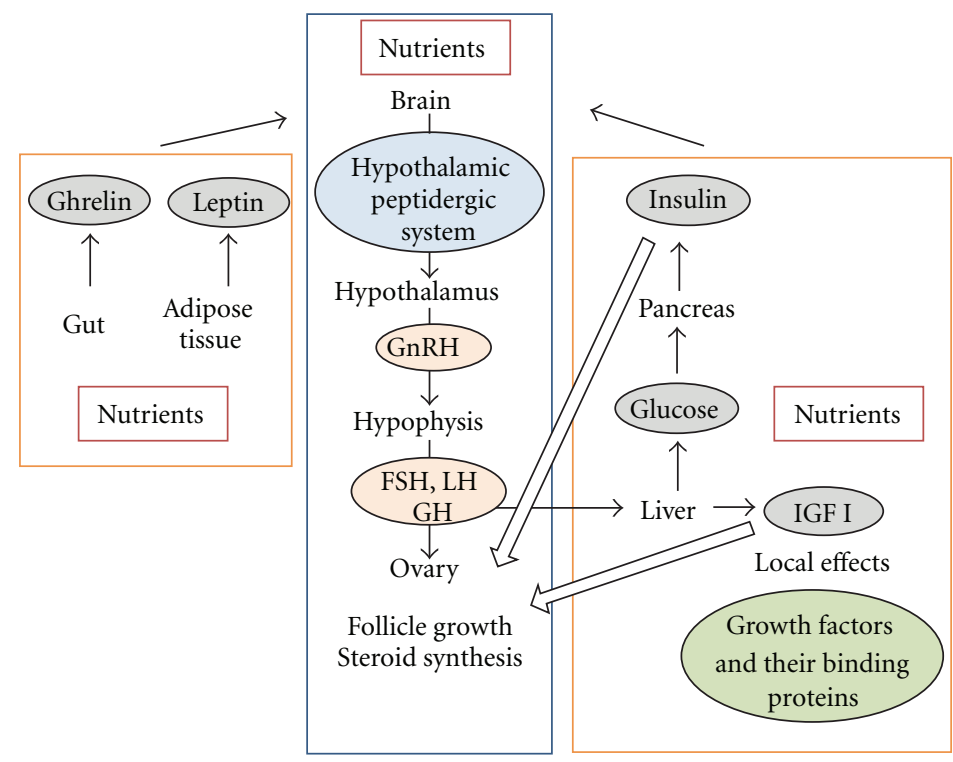

FIGURE 1: Schematic representation of mechanisms by which nutrition influences reproductive function.

the reproductive process. It has a major role in controlling the oestrous cycle, determining oestrous behaviour, ensuring oocyte competency and subsequent embryo survival rate, and determining both postovulation corpus luteum function and progesterone synthesis [42]. On the other side, gonadal function is regulated by the precise and coordinated secretion of the pituitary gonadotropins, luteinizing hormone ( $\mathrm{LH})$ and follicle-stimulating hormone (FSH) which is also modified by nutrition. In summary, folliculogenesis is a very complex but finely tuned process, in which endocrine and paracrine signals play an important role (for review, see [51]).

Folliculogenesis is stimulated by energy; particularly glucose is the main component of diet implied, although energy derived from fatty acid oxidation also appears to be important. On the other hand, proteins, vitamins, and other micronutrients probably exert permissive rather than regulatory functions on folliculogenesis [52]. The metabolic modulatory systems in follicular response are insulin-glucose, leptin and insulin-like growth factors (IGF) I and II and their binding proteins [53-55], which interact among them in a complex manner [4]. They are likely to be important mediators of the effects of dietary intake and/or energy balance [42].

Direct nutritional influence on ovary function depends on IGF-I from liver and on IGFBP concentrations, besides the reduction of follicular responsiveness of LH provoked by insulin suppressing follicular estradiol production below the threshold necessary to induce preovulatory-GnRH surge $[8,42]$. For example, in gilts, feeding increases responsiveness of the ovary to LH through increasing insulin and IGF-I concentrations [56]. In ewes, nutrition changes can modulate the ability of gonadotrophin-dependent follicles to use the small amounts of FSH at the final stages of follicle growth, which are the most sensitive to low FSH levels [57].

\section{Metabolic Signals That Control Energy Balance Linked to Reproduction}

In general, plasma concentrations of some hormones such as insulin [58], IGF-I [59], and leptin [60,61] augment when nutritional status improved by higher food intake or increased body fat depots. Conversely, they decrease with reduced food intake or increased tissue mobilization in pregnancy or lactation phases.

Available metabolic fuels modulate hormone input to GnRH neurones, leading in turn to altered $\mathrm{GnRH}$ release and appropriate drive to the gonads [5]. In next section a review of the main hormones and neuropeptides implicated in the control of nutrition and reproduction is showed.

3.1. Somatotropic Axis Hormones, Insulin, and Glucose. Somatotropic axis hormones consist of growth hormone (GH), the insulin-like growth factors I and II (IGF-I and IGF-II), $\mathrm{GH}$ binding protein (GHBP), IGF binding proteins (IGFBPs) 1 to 6 , and the cell-surface receptors for GH. GH as well as systemic and locally produced IGF can exert stimulatory, synergistic, or permissive effects at each level of the HPG axis, in the reproductive tract, external genitalia, and mammary gland [62]. This group of hormones has major effects on growth, lactation, and reproduction [63] and has a clear link with the metabolic status of the animals. Indeed, actions of GH and adequate levels of IGF-I in peripheral circulation are required to reach puberty and full reproductive potential [64].

GH seems to have a facilitatory rather than an obligatory role in reproduction [65]. It has direct effects on the follicle as well as indirect effects mediated by shifts in nutrient metabolism, insulin sensitivity, IGF-I, and IGFBP [64].

There are multiple levels of HPG axis at which IGFI can act to coordinate reproduction with growth. In this 
sense, IGF-I acts as a direct regulator of $\mathrm{GnRH}$ neuron, usually excitatory [66]. In addition, IGF-I can also regulate the HPG axis via actions at the pituitary [67] and gonadal levels [68]. For that reason, IGF-I is a potential link between the reproductive and somatotropic neuroendocrine systems [66]. Additionally, local production of IGF-I independently of $\mathrm{GH}$ plays an important role in the intricate paracrine control of function of different types of somatic cells in the ovary. Insulin growth factor I and the IGF binding proteins (IGFBPs) participate by means of various mechanisms in different stages of follicular development, follicular steroidogenesis $[51,69]$, and oocyte maturation $[70]$ as in the control of ovulation [71]. Therefore, insulin and IGF-I may be mediators between body condition and ovarian follicle development, ovulation and embryo development [50]. In fact, nutritionally induced changes in the ovarian IGF system play a key role in regulating oocyte quality [72].

Insulin is a modulator of the metabolic stimulus, rather than a mediator between the level of internal energy and the central effectors [8]. The common signaling pathway IGF-I receptor and insulin receptor (IR) signal through the insulin receptor substrate (IRS) proteins $[73,74]$ plays a role in regulating fertility under normal chow-fed conditions. Insulin has a direct effect at the ovarian level [4, 75]. Dietary restriction and NEB reduce circulating concentrations of insulin [76] and therefore could reduce androgen and estradiol production [77] which compromise the ability of follicles to acquire LH receptors [42]. Concentrations of insulin and IGF-I increase after a short-term supplementation, and they increase responsiveness to gonadotrophins, stimulate follicular growth, and suppress apoptosis in follicles $[12,53$, 78]. It is unknown which insulin profiles are optimal for good follicle quality and uniformity, and how these insulin profiles can be achieved [79]. However, insulin secretion pattern can also be modulated by diet composition and feeding frequency. In this sense, the modulation of plasma insulin levels by dietary carbohydrates seems possible in sows, but IGF-I levels are less easily modified [80]. However, supplementation of fatty acids in cow did not improved plasma insulin concentrations [81].

Availability of locally produced IGF II in follicles is controlled by locally produced IGF-binding proteins (IGFBPs) [82]. IGF-II can modify the function of follicular cells by changes in diet which altered IGFBP-2 and IGFBP-4 [2]. Low blood concentrations of IGFBP occurred by undernutrition [83] or severe NEB [84], limiting the availability of IGF to target cells in the follicle and regulating their ability to stimulate cell proliferation and steroidogenesis [85].

Glucose is a very important mediator of nutritional effects on reproduction. Blood concentrations are inversely correlated to energy intake [86]. Glucose is transported by the family of facilitative glucose transporters (GLUTs) which get involved in hypothalamic regulation [87] and also plays a major role in providing metabolic substrates to oocyte and embryo $[88,89]$. Glucose availability influences LH secretion through GnRH system [90]. Actually, numerous studies support the idea that glucose in particular mediates the effects of fasting to suppress GnRH-stimulated $\mathrm{LH}$ release. GnRH neurons might directly sense changes in glucose availability by a mechanism involving AMP-activated protein kinase [91]. On the other hand, glucose is the most important energy substrate for mammalian oocytes and blastocysts, so glucose deficiency can compromise the ability of the oocyte to reach the second metaphase, to extrude the first polar body [92] and to achieve the blastocyst stage. The changes in the role of glucose during preimplantation embryo development indicate that a specific interplay exists between glucose metabolism and the glucose transporters during different stages of preimplantation embryo development [93]. Besides, alterations in glucose transport and metabolism at the earliest stages of development can impact fetal development [88].

3.2. Adipokine Family: Leptin, Resistin, and Adiponectin. Adipokine family includes leptin, resistin, and adiponectin. Normal levels of adipokines are fundamental to maintain integrity of HPG axis, regular ovulatory processes, successful embryo implantation, and physiologic pregnancy [94].

Leptin is a $16 \mathrm{kD}$ protein consisting of 146 amino acids which is synthesized primarily by adipose tissue. This protein was first identified as the gene product found to be deficient in the obese ob/ob mouse [95]. It is considered a potent satiety factor [96], and their concentrations in plasma reflect the amount of body fat [97]. Leptin modulates a diverse range of biological functions, including energy homeostasis and reproduction $[98,99]$. In fact, the impact of leptin on feed intake, neuroendocrine-axis, and immunological processes has been demonstrated [100]. For that reason, leptin has been considered as the key link between nutrition and reproduction, like the appropriate signal to inform the reproductive system about the metabolic status [99].

Leptin is a permissive signal for puberty onset [101, 102], since a threshold of leptin is necessary for normal puberty to occur $[103,104]$. The hypothalamus is an important site of leptin's action. Leptin is a potent stimulator of central $\mathrm{GnRH}$ and gonadotropin secretion $[105,106]$. In addition, leptin has a direct effect on ovary being a potent inhibitor of ovarian steroidogenesis $[107,108]$. In the ovary, leptin antagonizes the stimulatory effect of insulin on theca cell steroidogenesis, ultimately leading to a decrease in oestradiol secretion [109]. It also affects oocyte maturation [110], follicle rupture, corpus luteum formation [111], embryo implantation, and pregnancy [112]. Last study of Zhang et al. [113] suggests that role of leptin can be mediated by divergent modulation by gonadotropins even of a direct ovary effect.

Leptin concentrations are sensitive to short-term alterations in food intake and energy balance [114, 115]. Leptin presents the ability to increase fuel oxidation [8], influences whole-body glucose homeostasis and the action of insulin. Insulin sensitivity is impaired by leptin [116], and leptin production indirectly increases by insulin since insulin stimulates the secretion of leptin by adipocytes and by promoting lipogenesis [117].

The important role of leptin as link between nutrition and reproduction could be evidenced since although $\mathrm{GnRH}$ neurons do not express leptin receptors under physiological conditions, leptin influences GnRH neuron activity via 
regulation of immediate downstream mediators including the neuropeptides neuropeptide $\mathrm{Y}$ and the melanocortin agonist and antagonist (alpha-MSH and agouti-related peptide) $[118,119]$. Besides, leptin promotes GnRH function via an indirect action on kisspeptin neurons $[120,121]$.

The other two adipokines have been less studied, and the central roles of adiponectin and resistin are less clear. Resistin impairs insulin sensitivity as leptin, whereas adiponectin enhances it. Adiponectin significantly reduced GnRH secretion [122] and inhibits GH and LH release [123]. In the ovary, adiponectin stimulates steroidogenesis by granulosa cells [116]. Resistin is expressed in rat and bovine ovaries and can modulate granulose cells functions in basal state or in response to IGF-I in vitro [124]. Resistin preferentially inhibits steroidogenesis of undifferentiated (small follicle) granulosa cells and inhibits proliferation of differentiated (large follicle) granulosa cells, indicating that the ovarian response to resistin is altered during follicular development [125].

3.3. Ghrelin. The peptide ghrelin was discovered by Kojima et al. [126] and identified an acylated 28 residue peptide released from the gut as the endogenous bioactive ligand for the growth hormone secretagogue receptor (GHS-R) type 1a. Ghrelin is involved in a wide spectrum of biological functions, including GH secretion and energy balance regulation, and exhibits diverse effects, including ones on glucose metabolism and on secretion and motility of the gastrointestinal tract [127]. The role of ghrelin in metabolism is the regulation of energy homeostasis, promoting food intake and weight gain [128]. The net orexigenic effect of ghrelin results is functionally opposite to that produced by leptin [129], and many data support the notion that both hormones act in a complementary fashion in providing the central nervous system information about the energy balance for the maintenance of homeostasis [130-132].

Serum ghrelin levels are influenced by both short- and long-term changes in energy homeostasis (i.e., with glucose, insulin, and somatostatin levels) [133]. Ghrelin is considered as a signal of starvation or energy insufficiency with a negative correlation observed between body mass index (BMI) and ghrelin levels. In this sense, normal timing of puberty can be delayed if ghrelin levels are persistently elevated as putative signal for energy insufficiency [118]. In the control of the reproductive function, ghrelin shows a complex mode of action upon the gonadotropic axis, with predominant inhibitory effects at central (hypothalamic) levels and upon GnRH-induced gonadotropin secretion, but direct stimulatory actions on basal LH and FSH secretion [134]. Gonadal physiology is also regulated by grhelin [118, $127,135]$ and even in preimplantation period [133] although the mechanism remains unclear to date.

3.4. Neuropeptides and Modulators. Neuropeptides including neuropeptide Y (NPY), products of the proopiomelanocortin (the proopiomelanocortin-(POMC-) derived peptide and alpha-melanocyte-stimulating hormone (alpha-MSH)), galanin-like peptide (GALP), and kisspeptins are thought to be implicated in the control of metabolism and reproduction. The involvement is supposed because neurons that express these neuropeptides all reside in the hypothalamic arcuate nucleus, a critical site for the regulation of both metabolism and reproduction. In addition, these neuropeptides are all targets for regulation by metabolic hormones, such as leptin and insulin. And finally, these neuropeptides have either direct or indirect effects on feeding and metabolism, as well as on the secretion of GnRH and LH [136]. The discovery of kisspeptins and gonadotropininhibitory hormone $(\mathrm{GnIH})$ sheds a new light on mechanisms by which reproductive activity is regulated. Other molecules such as the GnRH II, orexins, and nesfatin-1 have revealed also a role in the control of metabolism and reproduction.

3.4.1. Neuropeptide $Y$ (NPY). Neuropeptide $\mathrm{Y}$, the most potent orexigenic peptide known [99], is a 36-amino acid peptide neurotransmitter. It has a dual function in relation to reproduction and appetite [137]. It stimulates food intake and negatively regulates reproduction $[138,139]$ because it inhibits LH secretion [140, 141]. NPY seems to be implicated in the generation of the preovulatory surge of LH [142].

3.4.2. Melanocortin System. The melanocortin system, involving melanocyte stimulating hormone, adrenocorticotropic hormone, agouti-related peptide and the central melanocortin 3 and 4 receptors, plays a major role in the hypothalamic regulation of energy balance [143]. Conversely to NPY, melanocortin signaling controls ingestive behavior, energy balance, and substrate utilization [99] by means of reducing food intake and stimulating reproduction $[144,145]$. Melanocortin has recently demonstrated to be an important component in the leptin-mediated regulation of GnRH neuron activity, initiation of puberty and fertility $[119,146]$.

3.4.3. Galanin-Like Peptide (GALP). Galanin-like peptide (GALP) is a 60-amino acid neuropeptide which belongs to the $\mathrm{G}$ protein-coupled receptors (GPCRs) family. GALP is mainly produced in neurons in the hypothalamic arcuate nucleus. The effects of GALP on food intake and body weight are complex. In rats, the central effect of GALP is to first stimulate and then reduce food intake, whereas in mice, GALP has an anorectic function. Furthermore, GALP shows direct stimulatory action on gonadotropin secretion [147, 148], regulates plasma LH levels through activation of GnRH producing neurons, suggesting that it is also involved in the reproductive system $[148,149]$. The presence of galanin within kisspeptin axons innervating GnRH neurones and the oestrogen-dependent regulation of that presence add a new dimension to the roles played by galanin in the central regulation of reproduction [150].

3.4.4. Kisspeptin. The Kiss1 gene encodes a family of peptides called kisspeptins, which bind to the G protein-coupled receptor GPR54. Humans and mice with loss-of-function mutations of the genes encoding kisspeptins (Kiss1) or 
kisspeptin receptor (Kiss1r) are infertile due to hypogonadotropic hypogonadism [151, 152]. The results from a wide variety of studies indicate that kisspeptin stimulates gonadotropin secretion via a hypothalamic pathway that activates GnRH neurons. Kisspeptins have emerged as important gatekeepers of key aspects of reproductive maturation and function, from sexual differentiation of the brain and puberty onset to adult regulation of gonadotropin secretion and the metabolic control of fertility (for review see [153]).

Hypothalamic Kiss1 neurons are highly sensitive to body energy status and metabolic cues, as evidenced by suppressed Kiss1/kisspeptin expression in conditions of negative energy balance, which are also linked to inhibition of the reproductive axis [154]. Kisspeptin neurons are downstream mediators of leptin's positive effect on the secretion of gonadotropins [154], and it is affected by leptin status [155]. Besides, network between Kisspeptin cells communicating with NPY and POMC cells seems to coordinate brain control of reproduction and metabolic homeostatic systems [155, 156]. Agonists and antagonists of kisspeptin have emerged as valuable new tools for manipulating the HPG axis and are promising drugs for future treatment [157].

3.4.5. Gonadotropin Inhibitory Hormone (GnIH). The gonadotropin inhibitory hormone $(\mathrm{GnIH})$ acts via the novel $\mathrm{G}$ protein-coupled receptor 147 (GPR147) to inhibit gonadotropin release and synthesis. It has also a dual role with a function in the regulation of reproduction and food intake [158]. It stimulates food intake in rats [159], and recent data indicate a direct action of $\mathrm{GnIH}$ on the pituitary gonadotrope to reduce both synthesis and secretion of LH (160), so it could be considered as a blocker of reproductive function in mammals [160]. Recent evidence further indicates that $\mathrm{GnIH}$ operates at the level of the gonads as an autocrine/paracrine regulator of steroidogenesis and gametogenesis (for review see [161]).

3.4.6. GnRH II. One form of gonadotropin releasing hormone $(\mathrm{GnRH})$ now called GnRH II acts as a permissive regulator of female reproductive behaviour based on energy status, as well as a modifier of short-term food intake [162]. GnRH II plays a critical role by orchestrating the coordination of reproduction with the availability of nutritional support [163].

3.4.7. Orexins. Orexins A and B are neuropeptides which are synthesized mainly in the lateral hypothalamus and are associated with a variety of physiological functions such as energy homeostasis and reproduction. The orexins activate two G-protein-coupled receptors termed orexin receptor 1 (OX1R) and orexin receptor 2 (OX2R). They are implicated in the regulation of $\mathrm{GnRH}$ cells [164] as a mechanism whereby leptin can influence reproductive neuroendocrine function. Also, orexin $\mathrm{A}$ is implicated in pulsatile LH secretion [165] which is potentiated by estrogen [166].
3.4.8. Nesfatin-1. Nesfatin-1 (NEFA/NUCB2-encoded satiety and fat-influencing protein) is a recently discovered and still relatively unknown hypothalamic peptide which can be considered as one of the regulatory factors of the hypothalamic-pituitary-axis. Nesfatin-1 is a potent anorexigenic factor inducing satiety and strongly inhibiting food and water intake $[167,168]$. It is implicated in the gonadotropin secretion during puberty [169], and these processes can be greatly disturbed by negative energy balance, caused by a short-term starvation or nutritional deficiency [170]. Further studies are required to involve Nesfatin-1 in regulation of gonadotropin secretion in adulthood [46].

\section{Effect of Maternal Nutrition on Fetal and Neonatal Reproductive Development and Function}

Maternal nutrition, mainly in periconceptional period, can have long-term consequences on health and well-being of the offspring. That has been termed developmental programming. In livestock, developmental programming affects production traits, including growth, body composition [171], and reproduction $[172,173]$. Latest studies are indicating the very important role of maternal nutrition on offspring development given that reproductive performance is clearly influenced by prenatal factors. Mechanisms by which environmental factors affect the reproductive organs of developing offspring are not well known to date neither the future consequences of maternal nutrition.

Maternal nutrition can influence development of the fetal reproductive system at all stages of development, during the processes of differentiation and development [174-176] and between birth and puberty [177, 178]; effects are exerted before neuroendocrine organs (like the hypothalamus and pituitary gland), and reproductive organs have been differentiated [179]. It involves many different physiological systems. Therefore, a wide range of mechanisms are involved (for review see [43]). For example, a recent study has elucidated that the sensitivity of Kiss1r mRNA, which is expressed in GnRH neuron, to nutritional status has been already established during the early neonatal period [180].

Scarce literature about effects of maternal nutrition on reproductive outcome of offspring has been reported. Nevertheless, maternal undernutrition and overnutrition or supplementation seems to impact on components of the HPG system of offspring [43]. For example, maternal undernutrition during the first month of pregnancy resulted in increased pituitary sensitivity to $\mathrm{GnRH}$ and increased number of small follicles in the ovary, while during mid to late gestation resulted in a reduction of large corpora lutea in female sheep offspring [181]. On the other hand, transgenerational supplementation with fish oil significantly decreased ovulation rate and litter size in female mice [182].

Further studies are required to better understand the impact of maternal nutrition on offspring future reproductive success. 


\section{Conclusion}

The finding of the protein leptin opened up a new time in the understanding of the neuroendocrine control of energy homeostasis and its close relationship with the reproductive axis [118]. In recent years, thanks to a dynamic development of molecular biology, a number of new regulatory neuropeptides have been identified and described. Recent discoveries have elucidated the important role of periphery factors, such as leptin, ghrelin, and insulin. However, they are integrated with a complex network of neuropeptides, whose actions are located upstream of the $\mathrm{GnRH}$ cell population in brain. For example, compelling evidence indicates that kisspeptins and their receptor represent key elements in the neuroendocrine control of reproduction. Besides, $\mathrm{GnIH}$ has fundamentally changed our understanding of hypothalamic control of reproduction. In addition, some local factors related to metabolic status are extremely important in ovarian regulation. In conclusion, integrative control of energy balance and reproduction is carried out by multiple metabolic and neuroendocrine signals that control reproduction in an intricate manner, even affecting next generations.

\section{References}

[1] M. P. Boland, P. Lonergan, and D. O'Callaghan, "Effect of nutrition on endocrine parameters, ovarian physiology, and oocyte and embryo development," Theriogenology, vol. 55, no. 6, pp. 1323-1340, 2001.

[2] D. G. Armstrong, J. G. Gong, and R. Webb, "Interactions between nutrition and ovarian activity in cattle: physiological, cellular and molecular mechanisms," Reproduction Supplement, vol. 61, pp. 403-414, 2003.

[3] M. P. Boland and P. Lonergan, "Effects of nutrition on fertility in dairy cows," Advanced Dairy Technology, vol. 15, pp. 19-33, 2005.

[4] R. J. Scaramuzzi, B. K. Campbell, J. A. Downing et al., "A review of the effects of supplementary nutrition in the ewe on the concentrations of reproductive and metabolic hormones and the mechanisms that regulate folliculogenesis and ovulation rate," Reproduction Nutrition Development, vol. 46, no. 4, pp. 339-354, 2006.

[5] J. J. Evans and G. M. Anderson, "Balancing ovulation and anovulation: integration of the reproductive and energy balance axes by neuropeptides," Human Reproduction Update, vol. 18, no. 3, pp. 313-332, 2012.

[6] F. H. Bronson, Mammalian Reproductive Biology, The University of Chicago Press, Chicago, Ill, USA, 1989.

[7] J. L. Cameron and C. Nosbisch, "Suppression of pulsatile luteinizing hormone and testosterone secretion during short term food restriction in the adult male rhesus monkey (Macaca mulatta)," Endocrinology, vol. 128, no. 3, pp. 15321540, 1991.

[8] J. E. Schneider, "Energy balance and reproduction," Physiology and Behavior, vol. 81, no. 2, pp. 289-317, 2004.

[9] F. F. Casanueva and C. Dieguez, "Neuroendocrine regulation and actions of leptin," Frontiers in Neuroendocrinology, vol. 20, no. 4, pp. 317-363, 1999.

[10] M. C. Lucy, "Mechanisms linking nutrition and reproduction in postpartum cows," Reproduction Supplement, vol. 61, pp. 415-427, 2003.
[11] V. M. Thorup, D. Edwards, and N. C. Friggens, "On-farm estimation of energy balance in dairy cows using only frequent body weight measurements and body condition score," Journal of Dairy Science, vol. 95, no. 4, pp. 1784-1793, 2012.

[12] R. Jorritsma, M. W. De Groot, P. L. A. M. Vos, T. A. M. Kruip, T. Wensing, and J. P. T. M. Noordhuizen, "Acute fasting in heifers as a model for assessing the relationship between plasma and follicular fluid NEFA concentrations," Theriogenology, vol. 60, no. 1, pp. 151-161, 2003.

[13] J. L. M. R. Leroy, G. Opsomer, A. Van Soom, I. G. F. Goovaerts, and P. E. J. Bols, "Reduced fertility in highyielding dairy cows: are the oocyte and embryo in danger? Part I. The importance of negative energy balance and altered corpus luteum function to the reduction of oocyte and embryo quality in high-yielding dairy cows," Reproduction in Domestic Animals, vol. 43, no. 5, pp. 612-622, 2008.

[14] M. Arias-Álvarez, R. M. García-García, P. G. Rebollar, L. Revuelta, P. Millán, and P. L. Lorenzo, "Influence of metabolic status on oocyte quality and follicular characteristics at different postpartum periods in primiparous rabbit does," Theriogenology, vol. 72, no. 5, pp. 612-623, 2009.

[15] R. R. Grummer, "Etiology of lipid-related metabolic disorders in periparturient dairy cows," Journal of Dairy Science, vol. 76, no. 12, pp. 3882-3896, 1993.

[16] J. K. Drackley, "ADSA foundation scholar award: biology of dairy cows during the transition period: the final frontier?" Journal of Dairy Science, vol. 82, no. 11, pp. 2259-2273, 1999.

[17] C. Kawashima, M. Matsui, T. Shimizu et al., "Nutritional factors that regulate ovulation of the dominant follicle during the first follicular wave postpartum in high-producing dairy cows," Journal of Reproduction and Development, vol. 58, no. 1, pp. 10-16.

[18] S. C. Liefers, R. F. Veerkamp, M. F. W. Te Pas, Y. Chilliard, and T. Van Der Lende, "Genetics and physiology of leptin in periparturient dairy cows," Domestic Animal Endocrinology, vol. 29, no. 1, pp. 227-238, 2005.

[19] W. R. Butler and R. D. Smith, "Interrelationships between energy balance and postpartum reproductive function in dairy cattle," Journal of Dairy Science, vol. 72, no. 3, pp. 767783, 1989.

[20] E. J. Austin, M. Mihm, A. C. O. Evans et al., "Alterations in intrafollicular regulatory factors and apoptosis during selection of follicles in the first follicular wave of the bovine estrous cycle," Biology of Reproduction, vol. 64, no. 3, pp. 839848, 2001.

[21] S. W. Walsh, J. P. Mehta, P. A. McGettigan et al., "Effects of nutrition and metabolic status on circulating hormones and ovarian follicle development in cattle," Physiological Genomics, vol. 44, no. 9, pp. 504-517, 2012.

[22] J. L. M. R. Leroy, D. Rizos, R. Sturmey et al., "Intrafollicular conditions as a major link between maternal metabolism and oocyte quality: a focus on dairy cow fertility," Reproduction Fertility and Development, vol. 24, no. 1, pp. 1-12, 2012.

[23] C. Castellini, A. Dal Bosco, M. Arias-Álvarez, P. L. Lorenzo, R. Cardinali, and P. G. Rebollar, "The main factors affecting the reproductive performance of rabbit does: a review," Animal Reproduction Science, vol. 122, no. 3-4, pp. 174-182, 2010.

[24] J. D. Armstrong and J. H. Britt, "Nutritionally-induced anestrus in gilts: metabolic and endocrine changes associated with cessation and resumption of estrous cycles," Journal of Animal Science, vol. 65, no. 2, pp. 508-523, 1987.

[25] R. E. Short and R. A. Bellows, "Relationships among weight gains, age at puberty and reproductive performance in heifers," Journal of Animal Science, vol. 32, pp. 127-131, 1971. 
[26] K. L. Houseknecht, D. L. Boggs, D. R. Campion et al., "Effect of dietary energy source and level on serum growth hormone, insulin-like growth factor 1, growth and body composition in beef heifers," Journal of Animal Science, vol. 66, no. 11, pp. 2916-2923, 1988.

[27] J. L. Sartin, F. F. Bartol, R. J. Kemppainen, G. Dieberg, D. Buxton, and E. Soyoola, "Modulation of growth hormonereleasing factor stimulated growth hormone secretion by plasma glucose and free fatty acid concentrations in sheep," Neuroendocrinology, vol. 48, no. 6, pp. 627-633, 1988.

[28] R. M. García-García, P. G. Rebollar, M. Arias-Álvarez et al., "Acute fasting before conception affects metabolic and endocrine status without impacting follicle and oocyte development and embryo gene expression in the rabbit," Reproduction, Fertility and Development, vol. 23, no. 6, pp. 759-768, 2011.

[29] S. M. Rhind, S. McMillen, W. A. C. McKelvey, F. F. RodriguezHerrejon, and A. S. McNeilly, "Effect of the body condition of ewes on the secretion of LH and FSH and the pituitary response to gonadotrophin-releasing hormone," Journal of Endocrinology, vol. 120, no. 3, pp. 497-502, 1989.

[30] Z. Kiyma, B. M. Alexander, E. A. Van Kirk, W. J. Murdoch, D. M. Hallford, and G. E. Moss, "Effects of feed restriction on reproductive and metabolic hormones in ewes," Journal of Animal Science, vol. 82, no. 9, pp. 2548-2557, 2004.

[31] B. M. Alexander, Z. Kiyma, M. McFarland et al., "Influence of short-term fasting during the luteal phase of the estrous cycle on ovarian follicular development during the ensuing proestrus of ewes," Animal Reproduction Science, vol. 97, no. 3-4, pp. 356-363, 2007.

[32] J. Yan, B. Zhou, J. Yang et al., "Glucose can reverse the effects of acute fasting on mouse ovulation and oocyte maturation," Reproduction, Fertility and Development, vol. 20, no. 6, pp. 703-712, 2008.

[33] E. Borowczyk, J. S. Caton, D. A. Redmer et al., "Effects of plane of nutrition on in vitro fertilization and early embryonic development in sheep," Journal of Animal Science, vol. 84, no. 6, pp. 1593-1599, 2006.

[34] G. Brecchia, A. Bonanno, G. Galeati et al., "Hormonal and metabolic adaptation to fasting: effects on the hypothalamicpituitary-ovarian axis and reproductive performance of rabbit does," Domestic Animal Endocrinology, vol. 31, no. 2, pp. 105-122, 2006.

[35] K. J. Brothers, S. Wu, S. A. Divall et al., "Rescue of obesityinduced infertility in female mice due to a pituitary-specific knockout of the insulin receptor," Cell Metabolism, vol. 12, no. 3, pp. 295-305, 2010.

[36] S. C. Sagae, E. F. Menezes, M. L. Bonfleur et al., "Early onset of obesity induces reproductive deficits in female rats," Physiology and Behavior, vol. 105, no. 5, pp. 1104-1111, 2012.

[37] S. H. Purcell and K. H. Moley, "The impact of obesity on egg quality," Journal of Assisted Reproduction and Genetics, vol. 28, pp. 517-524, 2011.

[38] X. Yang, L. L. Wu, L. R. Chura et al., "Exposure to lipidrich follicular fluid is associated with endoplasmic reticulum stress and impaired oocyte maturation in cumulus-oocyte complexes," Fertility and Sterility, vol. 97, no. 6, pp. 14381443, 2012.

[39] J. A. Downing, J. Joss, and R. J. Scaramuzzi, "Ovulation rate and the concentrations of gonadotrophins and metabolic hormones in ewes infused with glucose during the late luteal phase of the oestrous cycle," Journal of Endocrinology, vol. 146, no. 3, pp. 403-410, 1995.
[40] S. J. Adamiak, K. Mackie, R. G. Watt, R. Webb, and K. D. Sinclair, "Impact of nutrition on oocyte quality: cumulative effects of body composition and diet leading to hyperinsulinemia in cattle," Biology of Reproduction, vol. 73, no. 5, pp. 918-926, 2005.

[41] M. Acosta-Martinez, "PI3K: an attractive candidate for the central integration of metabolism and reproduction," Frontiers in Endocrinology, vol. 2, article 110, 2011.

[42] M. G. Diskin, D. R. Mackey, J. F. Roche, and J. M. Sreenan, "Effects of nutrition and metabolic status on circulating hormones and ovarian follicle development in cattle," Animal Reproduction Science, vol. 78, no. 3-4, pp. 345-370, 2003.

[43] S. M. Rhind, "Effects of maternal nutrition on fetal and neonatal reproductive development and function," Animal Reproduction Science, vol. 82-83, pp. 169-181, 2004.

[44] H. Quesnel, A. Pasquier, A. M. Mounier, and A. Prunier, "Feed restriction in cyclic gilts: gonadotrophin-independent effects on follicular growth," Reproduction Nutrition Development, vol. 40, no. 4, pp. 405-414, 2000.

[45] A. Prunier and H. Quesnel, "Nutritional influences on the hormonal control of reproduction in female pigs," Livestock Production Science, vol. 63, no. 1, pp. 1-16, 2000.

[46] A. Palasz, M. Krzystanek, J. Worthington et al., "Nesfatin-1, a unique regulatory neuropeptide of the brain," Neuropeptides, vol. 46, no. 3, pp. 105-112, 2012.

[47] M. Tena-Sempere, "Ghrelin and reproduction, ghrelin as novel regulator of the gonadotropic axis," Vitamins and Hormones, vol. 77, pp. 285-300, 2008.

[48] K. Kirsz and D. A. Zieba, "Selected hypothalamic factors integrating reproduction and energy balance control in animals," Medycyna Weterynaryjna, vol. 68, no. 1, pp. 35-39, 2012.

[49] B. E. Howland, "Effect of glucoprivation induced by 2-deoxyD-glucose on serum gonadotropin levels, pituitary response to GnRH and progesterone-induced release of luteinizing hormone in rats," Hormone and Metabolic Research, vol. 12, no. 10 , pp. 520-523, 1980.

[50] L. M. Chagas, J. J. Bass, D. Blache et al., "Invited review: new perspectives on the roles of nutrition and metabolic priorities in the subfertility of high-producing dairy cows," Journal of Dairy Science, vol. 90, no. 9, pp. 4022-4032, 2007.

[51] R. Webb, P. C. Garnsworthy, J. G. Gong, and D. G. Armstrong, "Control of follicular growth: local interactions and nutritional influences," Journal of Animal Science, vol. 82, pp. E63-74, 2004.

[52] R. J. Scaramuzzi, H. M. Brown, and J. Dupont, "Nutritional and metabolic mechanisms in the ovary and their role in mediating the effects of diet on folliculogenesis: a perspective," Reproduction in Domestic Animals, vol. 45, no. 3, pp. 32-41, 2010.

[53] S. A. Williams, D. Blache, G. B. Martin, R. Foot, M. A. Blackberry, and R. J. Scaramuzzi, "Effect of nutritional supplementation on quantities of glucose transporters 1 and 4 in sheep granulosa and theca cells," Reproduction, vol. 122, no. 6, pp. 947-956, 2001.

[54] M. Muñoz-Gutiérrez, D. Blache, G. B. Martin, and R. J. Scaramuzzi, "Ovarian follicular expression of mRNA encoding the type I IGF receptor and IGF-binding protein-2 in sheep following five days of nutritional supplementation with glucose, glucosamine or lupins," Reproduction, vol. 128, no. 6, pp. 747-756, 2004.

[55] M. G. Hunter, R. S. Robinson, G. E. Mann, and R. Webb, “Endocrine and paracrine control of follicular development and 
ovulation rate in farm species," Animal Reproduction Science, vol. 82-83, pp. 461-477, 2004.

[56] J. R. Cosgrove, J. E. Tilton, M. G. Hunter, and G. R. Foxcroft, "Gonadotropin-independent mechanisms participate in ovarian responses to realimentation in feed-restricted prepubertal gilts," Biology of Reproduction, vol. 47, no. 5, pp. 736-745, 1992.

[57] C. J. H. Souza, B. K. Campbell, and D. T. Baird, "Follicular dynamics and ovarian steroid secretion in sheep during the follicular and early luteal phases of the estrous cycle," Biology of Reproduction, vol. 56, no. 2, pp. 483-488, 1997.

[58] J. M. Wallace, R. P. Aitken, and M. A. Cheyne, "Nutrient partitioning and fetal growth in rapidly growing adolescent ewes," Journal of Reproduction and Fertility, vol. 107, no. 2, pp. 183-190, 1996.

[59] S. M. Rhind, S. R. Mcmillen, E. Duff, D. Hirst, and S. Wright, "Seasonality of meal patterns and hormonal correlates in red deer," Physiology and Behavior, vol. 65, no. 2, pp. 295-302, 1998.

[60] L. J. Hardie, D. V. Rayner, S. Holmes, and P. Trayhurn, "Circulating leptin levels are modulated by fasting, cold exposure and insulin administration in lean but not Zucker ( $\mathrm{fa} / \mathrm{fa}$ ) rats as measured by ELISA," Biochemical and Biophysical Research Communications, vol. 223, no. 3, pp. 660-665, 1996.

[61] C. S. Mantzoros, D. Qu, R. C. Frederich et al., "Activation of $\beta 3$ adrenergic receptors suppresses leptin expression and mediates a leptin-independent inhibition of food intake in mice," Diabetes, vol. 45, no. 3, pp. 909-914, 1996.

[62] V. Chandrashekar, D. Zaczek, and A. Bartke, "The consequences of altered somatotropic system on reproduction," Biology of Reproduction, vol. 71, no. 1, pp. 17-27, 2004.

[63] M. C. Lucy, "Growth hormone regulation of follicular growth," Reproduction Fertility and Development, vol. 24, no. 1, pp. 19-28, 2012.

[64] J. A. Ramaley and C. K. Phares, "Delay of puberty onset in females due to suppression of growth hormone," Endocrinology, vol. 106, no. 6, pp. 1989-1993, 1980.

[65] M. C. Lucy, C. R. Bilby, C. J. Kirby, W. Yuan, and C. K. Boyd, "Role of growth hormone in development and maintenance of follicles and corpora lutea," Journal of Reproduction and Fertility. Supplement, vol. 54, pp. 49-59, 1999.

[66] S. S. Daftary and A. C. Gore, "IGF-1 in the brain as a regulator of reproductive neuroendocrine function," Experimental Biology and Medicine, vol. 230, no. 5, pp. 292-306, 2005.

[67] C. L. Adam, P. A. Findlay, and A. H. Moore, "Effects of insulin-like growth factor-1 on luteinizing hormone secretion in sheep," Animal Reproduction Science, vol. 50, no. 1-2, pp. 45-56, 1998.

[68] G. F. Erickson, V. G. Garzo, and D. A. Magoffin, "Insulinlike growth factor-I regulates aromatase activity in human granulosa and granulosa luteal cells," Journal of Clinical Endocrinology and Metabolism, vol. 69, no. 4, pp. 716-724, 1989.

[69] I. Demeestere, C. Gervy, J. Centner, F. Devreker, Y. Englert, and A. Delbaere, "Effect of insulin-like growth factor-I during preantral follicular culture on steroidogenesis, in vitro oocyte maturation, and embryo development in mice," Biology of Reproduction, vol. 70, no. 6, pp. 1664-1669, 2004.

[70] P. L. Lorenzo, P. G. Rebollar, M. J. Illera, J. C. Illera, M. Illera, and J. M. R. Alvarino, "Stimulatory effect of insulinlike growth factor I and epidermal growth factor on the maturation of rabbit oocytes in vitro," Journal of Reproduction and Fertility, vol. 107, no. 1, pp. 109-117, 1996.
[71] S. Mazerbourg, C. A. Bondy, J. Zhou, and P. Monget, "The insulin-like growth factor system: a key determinant role in the growth and selection of ovarian follicles? A comparative species study," Reproduction in Domestic Animals, vol. 38, no. 4, pp. 247-258, 2003.

[72] D. G. Armstrong, T. G. McEvoy, G. Baxter et al., "Effect of dietary energy and protein on bovine follicular dynamics and embryo production in vitro: associations with the ovarian insulin-like growth factor system," Biology of Reproduction, vol. 64, no. 6, pp. 1624-1632, 2001.

[73] J. Nakae, Y. Kido, and D. Accili, "Distinct and overlapping functions of insulin and IGF-I receptors," Endocrine Reviews, vol. 22, no. 6, pp. 818-835, 2001.

[74] J. J. Kim and D. Accili, "Signalling through IGF-I and insulin receptors: where is the specificity?" Growth Hormone and IGF Research, vol. 12, no. 2, pp. 84-90, 2002.

[75] P. C. Garnsworthy, A. Lock, G. E. Mann, K. D. Sinclair, and R. Webb, "Nutrition, metabolism, and fertility in dairy cows: 1. Dietary energy source and ovarian function," Journal of Dairy Science, vol. 91, no. 10, pp. 3814-3823, 2008.

[76] J. A. Vizcarra, R. P. Wettemann, J. C. Spitzer, and D. G. Morrison, "Body condition at parturition and postpartum weight gain influence luteal activity and concentrations of glucose, insulin, and nonesterified fatty acids in plasma of primiparous beef cows," Journal of Animal Science, vol. 76, no. 4, pp. 927-936, 1998.

[77] R. J. Scaramuzzi, J. F. Murray, J. A. Downing, and B. K. Campbell, "The effects of exogenous growth hormone on follicular steroid secretion and ovulation rate in sheep," Domestic Animal Endocrinology, vol. 17, no. 2-3, pp. 269-277, 1999.

[78] P. Monget and G. B. Martin, "Involvement of insulin-like growth factors in the interactions between nutrition and reproduction in female mammals," Human Reproduction, vol. 12, pp. 33-52, 1997.

[79] J. G. M. Wientjes, N. M. Soede, H. Van den Brand, and B. Kemp, "Nutritionally induced relationships between insulin levels during the weaning-to-ovulation interval and reproductive characteristics in multiparous sows: I. luteinizing hormone, follicle development, oestrus and ovulation," Reproduction in Domestic Animals, vol. 47, no. 1, pp. 53-61, 2012.

[80] J. G. M. Wientjes, N. M. Soede, F. Aarsse et al., "Effects of dietary carbohydrate sources on plasma glucose, insulin and IGF-I levels in multiparous sows," Journal of Animal Physiology and Animal Nutrition, vol. 96, no. 3, pp. 494-505, 2012.

[81] P. C. Garnsworthy, A. Lock, G. E. Mann, K. D. Sinclair, and R. Webb, "Nutrition, metabolism, and fertility in dairy cows: 2. Dietary fatty acids and ovarian function," Journal of Dairy Science, vol. 91, no. 10, pp. 3824-3833, 2008.

[82] R. Webb, B. Nicholas, J. G. Gong et al., "Mechanisms regulating follicular development and selection of the dominant follicle," Reproduction Supplement, vol. 61, pp. 71-90, 2003.

[83] M. A. Fenwick, R. Fitzpatrick, D. A. Kenny et al., "Interrelationships between negative energy balance (NEB) and IGF regulation in liver of lactating dairy cows," Domestic Animal Endocrinology, vol. 34, no. 1, pp. 31-44, 2008.

[84] S. Llewellyn, R. Fitzpatrick, D. A. Kenny, J. J. Murphy, R. J. Scaramuzzi, and D. C. Wathes, "Effect of negative energy balance on the insulin-like growth factor system in prerecruitment ovarian follicles of post partum dairy cows," Reproduction, vol. 133, no. 3, pp. 627-639, 2007. 
[85] R. Webb, R. G. Gosden, E. E. Telfer, and R. M. Moor, "Factors affecting folliculogenesis in ruminants," Animal Science, vol. 68, no. 2, pp. 257-284, 1999.

[86] J. V. Yelich, R. P. Wettemann, T. T. Marston, and L. J. Spicer, "Luteinizing hormone, growth hormone, insulin-like growth factor-I, insulin and metabolites before puberty in heifers fed to gain at two rates," Domestic Animal Endocrinology, vol. 13, no. 4, pp. 325-338, 1996.

[87] V. M. Harris, S. V. Bendre, F. G. De Los Santos et al., "GnRH increases glucose transporter-1 expression and stimulates glucose uptake in the gonadotroph," Journal of Endocrinology, vol. 212, no. 2, pp. 139-147, 2012.

[88] S. H. Purcell and K. H. Moley, "Glucose transporters in gametes and preimplantation embryos," Trends in Endocrinology and Metabolism, vol. 20, no. 10, pp. 483-489, 2009.

[89] Q. Wang, M. M. Chi, T. Schedl et al., "An intercellular pathway for glucose transport into mouse oocytes," American Journal of Physiology-Endocrinology and Metabolism, vol. 302, no. 12, pp. E1511-E1518, 2012.

[90] D. C. Bucholtz, N. M. Vidwans, C. G. Herbosa, K. K. Schillo, and D. L. Foster, "Metabolic interfaces between growth and reproduction. V. Pulsatile luteinizing hormone secretion is dependent on glucose availability," Endocrinology, vol. 137, no. 2, pp. 601-607, 1996.

[91] A. V. Roland and S. M. Moenter, "Regulation of gonadotropin-releasing hormone neurons by glucose," Trends in Endocrinology and Metabolism, vol. 22, no. 11, pp. 443-449, 2011.

[92] T. Domiko and N. L. First, "Timing of meiotic progression in bovine oocytes and its effect on early embryo development," Molecular Reproduction and Development, vol. 47, pp. 456467, 1997.

[93] G. Leppens-Luisier, F. Urner, and D. Sakkas, "Facilitated glucose transporters play a crucial role throughout mouse preimplantation embryo development," Human Reproduction, vol. 16, no. 6, pp. 1229-1236, 2001.

[94] C. Tersigni, F. Di Nicuolo, S. D’Ippolito, M. Veglia, M. Castellucci, and N. Di Simone, "Adipokines: new emerging roles in fertility and reproduction," Obstetrical and Gynecological Survey, vol. 66, no. 1, pp. 47-63, 2011.

[95] Y. Zhang, R. Proenca, M. Maffei, M. Barone, L. Leopold, and J. M. Friedman, "Positional cloning of the mouse obese gene and its human homologue," Nature, vol. 372, no. 6505, pp. 425-432, 1994.

[96] L. A. Campfield, F. J. Smith, Y. Guisez, R. Devos, and P. Burn, "Recombinant mouse OB protein: evidence for a peripheral signal linking adiposity and central neural networks," Science, vol. 269, no. 5223, pp. 546-549, 1995.

[97] G. P. McGregor, J. F. Desaga, K. Ehlenz et al., "Radioimmunological measurement of leptin in plasma of obese and diabetic human subjects," Endocrinology, vol. 137, no. 4, pp. 15011504, 1996.

[98] C. R. Barb, J. B. Barrett, R. R. Kraeling, and G. B. Rampacek, "Role of leptin in modulating neuroendocrine function: a metabolic link between the brain-pituitary and adipose tissue," Reproduction in Domestic Animals, vol. 34, no. 3-4, pp. 111-125, 1999.

[99] L. J. Clarke and B. A. Henry, "Leptin and reproduction," Reviews of Reproduction, vol. 4, no. 1, pp. 48-55, 1999.

[100] A. Cervero, F. Domínguez, J. A. Horcajadas, A. Quiñonero, A. Pellicer, and C. Simón, "The role of the leptin in reproduction," Current Opinion in Obstetrics and Gynecology, vol. 18, no. 3, pp. 297-303, 2006.
[101] R. S. Ahima, J. Dushay, S. N. Flier, D. Prabakaran, and J. S. Flier, "Leptin accelerates the onset of puberty in normal female mice," Journal of Clinical Investigation, vol. 99, no. 3, pp. 391-395, 1997.

[102] C. C. Cheung, J. E. Thornton, J. L. Kuijper, D. S. Weigle, D. K. Clifton, and R. A. Steiner, "Leptin is a metabolic gate for the onset of puberty in the female rat," Endocrinology, vol. 138, no. 2, pp. 855-858, 1997.

[103] M. Rosenbaum and R. L. Leibel, "Leptin: a molecule integrating somatic energy stores, energy expenditure and fertility," Trends in Endocrinology and Metabolism, vol. 9, no. 3, pp. 117-124, 1998.

[104] R. S. Ahima, C. B. Saper, J. S. Flier, and J. K. Elmquist, "Leptin regulation of neuroendocrine systems," Frontiers in Neuroendocrinology, vol. 21, no. 3, pp. 263-307, 2000.

[105] W. H. Yu, M. Kimura, A. Walczewska, S. Karanth, and S. M. McCann, "Role of leptin in hypothalamic-pituitary function," Proceedings of the National Academy of Sciences of the United States of America, vol. 94, pp. 1023-1028, 1997.

[106] S. M. McCann, M. Kimura, A. Walczewska, S. Karanth, V. Rettori, and W. H. Yu, "Hypothalamic control of FSH and LH by FSH-RF, LHRH, cytokines, leptin and nitric oxide," NeuroImmunomodulation, vol. 5, no. 3-4, pp. 193-202, 1998.

[107] L. J. Spicer, "Leptin: a possible metabolic signal affecting reproduction," Domestic Animal Endocrinology, vol. 21, no. 4, pp. 251-270, 2001.

[108] N. R. Kendall, C. G. Gutierrez, R. J. Scaramuzzi, D. T. Baird, R. Webb, and B. K. Campbell, "Direct in vivo effects of leptin on ovarian steroidogenesis in sheep," Reproduction, vol. 128, no. 6, pp. 757-765, 2004.

[109] L. J. Spicer and C. C. Francisco, "The adipose obese gene product, leptin: evidence of a direct inhibitory role in ovarian function," Endocrinology, vol. 138, no. 8, pp. 3374-3379, 1997.

[110] J. Craig, H. Zhu, P. W. Dyce, J. Petrik, and J. Li, "Leptin enhances oocyte nuclear and cytoplasmic maturation via the mitogen-activated protein kinase pathway," Endocrinology, vol. 145, no. 11, pp. 5355-5363, 2004.

[111] Z. T. Ruiz-Cortés, Y. Martel-Kennes, N. Y. Gévry, B. R. Downey, M. F. Palin, and B. D. Murphy, "Biphasic effects of leptin in porcine granulosa cells," Biology of Reproduction, vol. 68, no. 3, pp. 789-796, 2003.

[112] J. A. Craig, H. Zhu, P. W. Dyce, L. Wen, and J. Li, "Leptin enhances porcine preimplantation embryo development in vitro," Molecular and Cellular Endocrinology, vol. 229, no. 12, pp. 141-147, 2005.

[113] Y. Zhang, M. Hu, H. Ma et al., "The impairment of reproduction in $\mathrm{db} / \mathrm{db}$ mice is not mediated by intraovarian defective leptin signaling," Fertility and Sterility, vol. 97, no. 5, pp. 1183-1191, 2012.

[114] M. J. Cunningham, D. K. Clifton, and R. A. Steiner, "Leptin's actions on the reproductive axis: perspectives and mechanisms," Biology of Reproduction, vol. 60, no. 2, pp. 216-222, 1999.

[115] M. Marie, P. A. Findlay, L. Thomas, and C. L. Adam, "Daily patterns of plasma leptin in sheep: effects of photoperiod and food intake," Journal of Endocrinology, vol. 170, no. 1, pp. 277-286, 2001.

[116] P. Monget, C. Chabrolle, and J. Dupont, "Adipose tissue, nutrition and reproduction: what is the link?" Bulletin de l'Academie Nationale de Medecine, vol. 192, no. 4, pp. 637648, 2008. 
[117] L. Poretsky, N. A. Cataldo, Z. Rosenwaks, and L. C. Giudice, "The insulin-related ovarian regulatory system in health and disease," Endocrine Reviews, vol. 20, no. 4, pp. 535-582, 1999.

[118] M. Tena-Sempere, "Roles of ghrelin and leptin in the control of reproductive function," Neuroendocrinology, vol. 86, no. 3, pp. 229-241, 2007.

[119] D. D. Israel, S. Sheffer-Babila, C. de Luca et al., "Effects of leptin and melanocortin signaling interactions on pubertal development and reproduction," Endocrinology, vol. 153, pp. 2408-2419, 2012.

[120] M. Tena-Sempere, "GPR54 and kisspeptin in reproduction," Human Reproduction Update, vol. 12, no. 5, pp. 631-639, 2006.

[121] J. H. Quennell, C. S. Howell, J. Roa, R. A. Augustine, D. R. Grattan, and G. M. Anderson, "Leptin deficiency and dietinduced obesity reduce hypothalamic kisspeptin expression in mice," Endocrinology, vol. 152, no. 4, pp. 1541-1550, 2011.

[122] X. B. Cheng, J. P. Wen, J. Yang, Y. Yang, G. Ning, and X. Y. $\mathrm{Li}$, "GnRH secretion is inhibited by adiponectin through activation of AMP-activated protein kinase and extracellular signal-regulated kinase," Endocrine, vol. 39, no. 1, pp. 6-12, 2011.

[123] F. Rodriguez-Pacheco, A. J. Martinez-Fuentes, S. Tovar et al., "Regulation of pituitary cell function by adiponectin," Endocrinology, vol. 148, no. 1, pp. 401-410, 2007.

[124] V. Maillard, P. Froment, C. Ramé, S. Uzbekova, S. Elis, and J. Dupont, "Expression and effect of resistin on bovine and rat granulosa cell steroidogenesis and proliferation," Reproduction, vol. 141, no. 4, pp. 467-479, 2011.

[125] L. J. Spicer, N. B. Schreiber, D. V. Lagaly, P. Y. Aad, L. B. Douthit, and J. A. Grado-Ahuir, "Effect of resistin on granulosa and theca cell function in cattle," Animal Reproduction Science, vol. 124, no. 1-2, pp. 19-27, 2011.

[126] M. Kojima, H. Hosoda, Y. Date, M. Nakazato, H. Matsuo, and K. Kangawa, "Ghrelin is a growth-hormone-releasing acylated peptide from stomach,” Nature, vol. 402, no. 6762, pp. 656-660, 1999.

[127] T. Lorenzi, R. Meli, D. Marzioni et al., "Ghrelin: a metabolic signal affecting the reproductive system," Cytokine and Growth Factor Reviews, vol. 20, no. 2, pp. 137-152, 2009.

[128] M. Korbonits, A. P. Goldstone, M. Gueorguiev, and A. B. Grossman, "Ghrelin - a hormone with multiple functions," Frontiers in Neuroendocrinology, vol. 25, no. 1, pp. 27-68, 2004.

[129] K. Wynne, S. Stanley, B. McGowan, and S. R. Bloom, "Appetite control," Journal of Endocrinology, vol. 184, no. 2, pp. 291-318, 2005.

[130] J. K. Hidekitamura, T. Shimizu, S. Ishii, H. Sugihara, and I. Wakabayashi, "Central effect of ghrelin, an endogenous growth hormone secretagogue, on hypothalamic peptide gene expression," Endocrinology, vol. 141, no. 12, pp. 47974800, 2000.

[131] M. Nakazato, N. Murakami, Y. Date et al., "A role for ghrelin in the central regulation of feeding," Nature, vol. 409, no. 6817, pp. 194-198, 2001.

[132] N. Hattori, T. Saito, T. Yagyu, B. H. Jiang, K. Kitagawa, and C. Inagaki, "GH, GH receptor, $\mathrm{GH}$ secretagogue receptor, and Ghrelin expression in human T cells, B cells, and neutrophils," Journal of Clinical Endocrinology and Metabolism, vol. 86, no. 9, pp. 4284-4291, 2001.

[133] G. Muccioli, T. Lorenzi, M. Lorenzi et al., "Beyond the metabolic role of ghrelin: a new player in the regulation of reproductive function," Peptides, vol. 32, no. 12, pp. 25142521, 2011.
[134] M. C. García, M. López, C. V. Alvarez, F. Casanueva, M. TenaSempere, and C. Diéguez, "Role of ghrelin in reproduction," Reproduction, vol. 133, no. 3, pp. 531-540, 2007.

[135] M. Tena-Sempere, "Ghrelin as a pleotrophic modulator of gonadal function and reproduction," Nature Clinical Practice Endocrinology and Metabolism, vol. 4, no. 12, pp. 666-674, 2008.

[136] A. Crown, D. K. Clifton, and R. A. Steiner, "Neuropeptide signaling in the integration of metabolism and reproduction," Neuroendocrinology, vol. 86, no. 3, pp. 175-182, 2007.

[137] A. Wojcik and J. Polkowska, "Neuropeptide Y-a neuromodulatory link between nutrition and reproduction at the central nervous system level," Reproductive Biology, vol. 6, supplement 2, pp. 21-28, 2006.

[138] M. L. Barker-Gibb, C. J. Scott, J. H. Boublik, and I. J. Clarke, "The role of neuropeptide Y (NPY) in the control of LH secretion in the ewe with respect to season, NPY receptor subtype and the site of action in the hypothalamus," Journal of Endocrinology, vol. 147, no. 3, pp. 565-579, 1995.

[139] I. J. Clarke, K. Backholer, and A. J. Tilbrook, "Y2 receptorselective agonist delays the estrogen-induced luteinizing hormone surge in ovariectomized ewes, but Y1receptor-selective agonist stimulates voluntary food intake," Endocrinology, vol. 146, no. 2, pp. 769-775, 2005.

[140] J. K. McDonald, M. D. Lumpkin, and L. V. DePaolo, "Neuropeptide-Y suppresses pulsatile secretion of luteinizing hormone in ovariectomized rats: possible site of action," Endocrinology, vol. 125, no. 1, pp. 186-191, 1989.

[141] O. S. Gazal, L. S. Leshin, R. L. Stanko et al., "Gonadotropinreleasing hormone secretion into third-ventricle cerebrospinal fluid of cattle: correspondence with the tonic and surge release of luteinizing hormone and its tonic inhibition by suckling and neuropeptide Y," Biology of Reproduction, vol. 59, no. 3, pp. 676-683, 1998.

[142] D. W. F. Porter, A. M. Naylor, A. S. McNeilly, and D. W. Lincoln, "Endocrine actions of central neuropeptide $\mathrm{Y}$ in the ewe: activation of the hypothalamo-pituitary-adrenal axis by exogenous neuropeptide $\mathrm{Y}$ and role of endogenous neuropeptide $\mathrm{Y}$ in the secretion of luteinizing hormone during the oestrous cycle," Journal of Neuroendocrinology, vol. 5, no. 2, pp. 163-174, 1993.

[143] H. B. Schiöth and H. Watanobe, "Melanocortins and reproduction," Brain Research Reviews, vol. 38, no. 3, pp. 340-350, 2002.

[144] K. Backholer, J. Smith, and I. J. Clarke, "Melanocortins may stimulate reproduction by activating orexin neurons in the dorsomedial hypothalamus and kisspeptin neurons in the preoptic area of the ewe," Endocrinology, vol. 150, no. 12, pp. 5488-5497, 2009.

[145] K. Backholer, M. Bowden, K. Gamber, C. Bjørbæk, J. Iqbal, and I. J. Clarke, "Melanocortins mimic the effects of leptin to restore reproductive function in lean hypogonadotropic ewes," Neuroendocrinology, vol. 91, no. 1, pp. 27-40, 2010.

[146] J. G. Hohmann, T. H. Teal, D. K. Clifton et al., "Differential role of melanocortins in mediating leptin's central effects on feeding and reproduction," American Journal of Physiology, vol. 278, no. 1, pp. R50-R59, 2000.

[147] A. S. Kauffman, J. Buenzle, G. S. Fraley, and E. F. Rissman, "Effects of galanin-like peptide (GALP) on locomotion, reproduction, and body weight in female and male mice," Hormones and Behavior, vol. 48, no. 2, pp. 141-151, 2005.

[148] M. J. Cunningham, M. Shahab, K. L. Grove et al., "Galaninlike peptide as a possible link between metabolism and 
reproduction in the macaque," Journal of Clinical Endocrinology and Metabolism, vol. 89, no. 4, pp. 1760-1766, 2004.

[149] S. Shioda, H. Kageyama, F. Takenoya, and K. Shiba, "Galaninlike peptide: a key player in the homeostatic regulation of feeding and energy metabolism," International Journal of Obesity, vol. 35, no. 5, pp. 619-628, 2011.

[150] I. Kallo, B. Vida, L. Deli et al., "Co-localisation of kisspeptin with galanin or neurokinin $\mathrm{B}$ in afferents to mouse $\mathrm{GnRH}$ neurones," Journal Of Neuroendocrinology, vol. 24, no. 3, pp. 464-476, 2012.

[151] S. Funes, J. A. Hedrick, G. Vassileva et al., "The KiSS-1 receptor GPR54 is essential for the development of the murine reproductive system," Biochemical and Biophysical Research Communications, vol. 312, no. 4, pp. 1357-1363, 2003.

[152] N. De Roux, E. Genin, J. C. Carel, F. Matsuda, J. L. Chaussain, and E. Milgrom, "Hypogonadotropic hypogonadism due to loss of function of the KiSS1-derived peptide receptor GPR 54," Proceedings of the National Academy of Sciences of the United States of America, vol. 100, no. 19, pp. 10972-10976, 2003.

[153] L. Pinilla, E. Aguilar, C. Dieguez Millar, P. Robert, and M. Tena-Sempere, "Kisspeptins and reproduction: physiological roles and regulatory mechanisms," Physiological Reviews, vol. 92, no. 3, pp. 1235-1316, 2012.

[154] J. Roa, D. García-Galiano, J. M. Castellano, F. Gaytan, L. Pinilla, and M. Tena-Sempere, "Metabolic control of puberty onset: new players, new mechanisms," Molecular and Cellular Endocrinology, vol. 324, no. 1-2, pp. 87-94, 2010.

[155] K. Backholer, J. T. Smith, A. Rao et al., "Kisspeptin cells in the ewe brain respond to leptin and communicate with neuropeptide Y and proopiomelanocortin cells," Endocrinology, vol. 151, no. 5, pp. 2233-2243, 2010.

[156] J. M. Castellano, A. H. Bentsen, J. D. Mikkelsen, and M. Tena-Sempere, "Kisspeptins: bridging energy homeostasis and reproduction," Brain Research, vol. 1364, pp. 129-138, 2010.

[157] I. Dedes, "Kisspeptins and the control of gonadotrophin secretion," Systems Biology in Reproductive Medicine, vol. 58, no. 3, pp. 121-128, 2012.

[158] T. Ubuka, H. Lai, M. Kitani et al., "Gonadotropin-inhibitory hormone identification, cDNA cloning, and distribution in rhesus macaque brain," Journal of Comparative Neurology, vol. 517, no. 6, pp. 841-855, 2009.

[159] M. A. Johnson, K. Tsutsui, and G. S. Fraley, "Rat RFamiderelated peptide-3 stimulates $\mathrm{GH}$ secretion, inhibits $\mathrm{LH}$ secretion, and has variable effects on sex behavior in the adult male rat," Hormones and Behavior, vol. 51, no. 1, pp. 171-180, 2007.

[160] I. J. Clarke, J. T. Smith, B. A. Henry et al., "Gonadotropininhibitory hormone is a hypothalamic peptide that provides a molecular switch between reproduction and feeding," Neuroendocrinology, vol. 95, no. 4, pp. 305-316, 2012.

[161] K. Tsutsui, T. Ubuka, G. E. Bentley, and L. J. Kriegsfeld, "Gonadotropin-inhibitory hormone (GnIH): discovery, progress and prospect," General and Comparative Endocrinology, vol. 177, no. 3, pp. 305-314, 2012.

[162] A. S. Kauffman, "Emerging functions of gonadotropinreleasing hormone II in mammalian physiology and behaviour," Journal of Neuroendocrinology, vol. 16, no. 9, pp. 794-806, 2004.
[163] J. S. Schneider and E. F. Rissman, "Gonadotropin-releasing hormone II: a multi-purpose neuropeptide," Integrative and Comparative Biology, vol. 48, no. 5, pp. 588-595, 2008.

[164] J. Iqbal, S. Pompolo, T. Sakurai, and I. J. Clarke, "Evidence that orexin-containing neurones provide direct input to gonadotropin-releasing hormone neurones in the ovine hypothalamus," Journal of Neuroendocrinology, vol. 13, no. 12, pp. 1033-1041, 2001.

[165] S. Pu, M. R. Jain, P. S. Kalra, and S. P. Kalra, "Orexins, a novel family of hypothalamic neuropeptides, modulate pituitary luteinizing hormone secretion in an ovarian steroiddependent manner," Regulatory Peptides, vol. 78, no. 1-3, pp. 133-136, 1998.

[166] M. Furuta, T. Funabashi, and F. Kimura, "Suppressive action of orexin A on pulsatile luteinizing hormone secretion is potentiated by a low dose of estrogen in ovariectomized rats," Neuroendocrinology, vol. 75, no. 3, pp. 151-157, 2002.

[167] H. Shimizu, S. Oh-I, S. Okada, and M. Mori, "Nesfatin-1: an overview and future clinical application," Endocrine Journal, vol. 56, no. 4 , pp. 537-543, 2009.

[168] A. Stengel, M. Goebel, L. Wang, and Y. Taché, "Ghrelin, desacyl ghrelin and nesfatin-1 in gastric X/A-like cells: role as regulators of food intake and body weight," Peptides, vol. 31, no. 2, pp. 357-369, 2010.

[169] D. García-Galiano, V. M. Navarro, J. Roa et al., "The anorexigenic neuropeptide, nesfatin-1, is indispensable for normal puberty onset in the female rat," Journal of Neuroscience, vol. 30, no. 23, pp. 7783-7792, 2010.

[170] D. García-Galiano, V. M. Navarro, F. Gaytan, and M. TenaSempere, "Expanding roles of NUCB2/nesfatin-1 in neuroendocrine regulation," Journal of Molecular Endocrinology, vol. 45 , no. 5, pp. 281-290, 2010.

[171] J. F. Hocquette, "Endocrine and metabolic regulation of muscle growth and body composition in cattle," Animal, vol. 4, no. 11, pp. 1797-1809, 2010.

[172] H. Jammes, C. Junien, and P. Chavatte-Palmer, "Epigenetic control of development and expression of quantitative traits," Reproduction, Fertility and Development, vol. 23, no. 1, pp. 64-74, 2011.

[173] C. Dupont, A. G. Cordier, C. Junien, B. Mandon-Pépin, R. Levy, and P. Chavatte-Palmer, "Maternal environment and the reproductive function of the offspring," Theriogenology, vol. 78, no. 7, pp. 1405-1414, 2012.

[174] S. C. Borwick, S. M. Rhind, S. R. McMillen, and P. A. Racey, "Effect of undernutrition of ewes from the time of mating on fetal ovarian development in mid gestation," Reproduction, Fertility and Development, vol. 9, no. 7, pp. 711-715, 1997.

[175] M. T. Rae, S. Palassio, C. E. Kyle et al., "Effect of maternal undernutrition during pregnancy on early ovarian development and subsequent follicular development in sheep fetuses," Reproduction, vol. 122, no. 6, pp. 915-922, 2001.

[176] M. T. Rae, S. M. Rhind, P. A. Fowler, D. W. Miller, C. E. Kyle, and A. N. Brooks, "Effect of maternal undernutrition on fetal testicular steroidogenesis during the CNS androgenresponsive period in male sheep fetuses," Reproduction, vol. 124, no. 1, pp. 33-39, 2002.

[177] R. G. Gunn, D. A. Sim, and E. A. Hunter, "Effects of nutrition in-utero and in early-life on the subsequent lifetime reproductive-performance of scottish blackface ewes in 2 management-systems," Animal Science, vol. 60, pp. 223-230, 1995.

[178] S. M. Rhind, D. A. Elston, J. R. Jones, M. E. Rees, S. R. McMillen, and R. G. Gunn, "Effects of restriction of growth 
and development of Brecon Cheviot ewe lambs on subsequent lifetime reproductive performance," Small Ruminant Research, vol. 30, no. 2, pp. 121-126, 1998.

[179] P. Hyttel, J. Laurincik, D. Viuff et al., "Activation of ribosomal RNA genes in preimplantation cattle and swine embryos," Animal Reproduction Science, vol. 60, pp. 49-60, 2000.

[180] T. Iwasa, T. Matsuzaki, M. Murakami et al., "Sensitivities of mRNA expression levels of Kiss1 and its receptor, Kiss1r, to nutritional status are changed during the developmental period in female rats," Journal of Endocrinology, vol. 207, no. 2, pp. 195-202, 2010.

[181] B. Kotsampasi, S. Chadio, G. Papadomichelakis et al., "Effects of maternal undernutrition on the hypothalamic-pituitarygonadal axis function in female sheep offspring," Reproduction in Domestic Animals, vol. 44, no. 4, pp. 677-684, 2009.

[182] D. Yi, S. Zeng, and Y. Guo, "A diet rich in n-3 polyunsaturated fatty acids reduced prostaglandin biosynthesis, ovulation rate, and litter size in mice," Theriogenology, vol. 78, no. 1, pp. 28-38, 2012. 

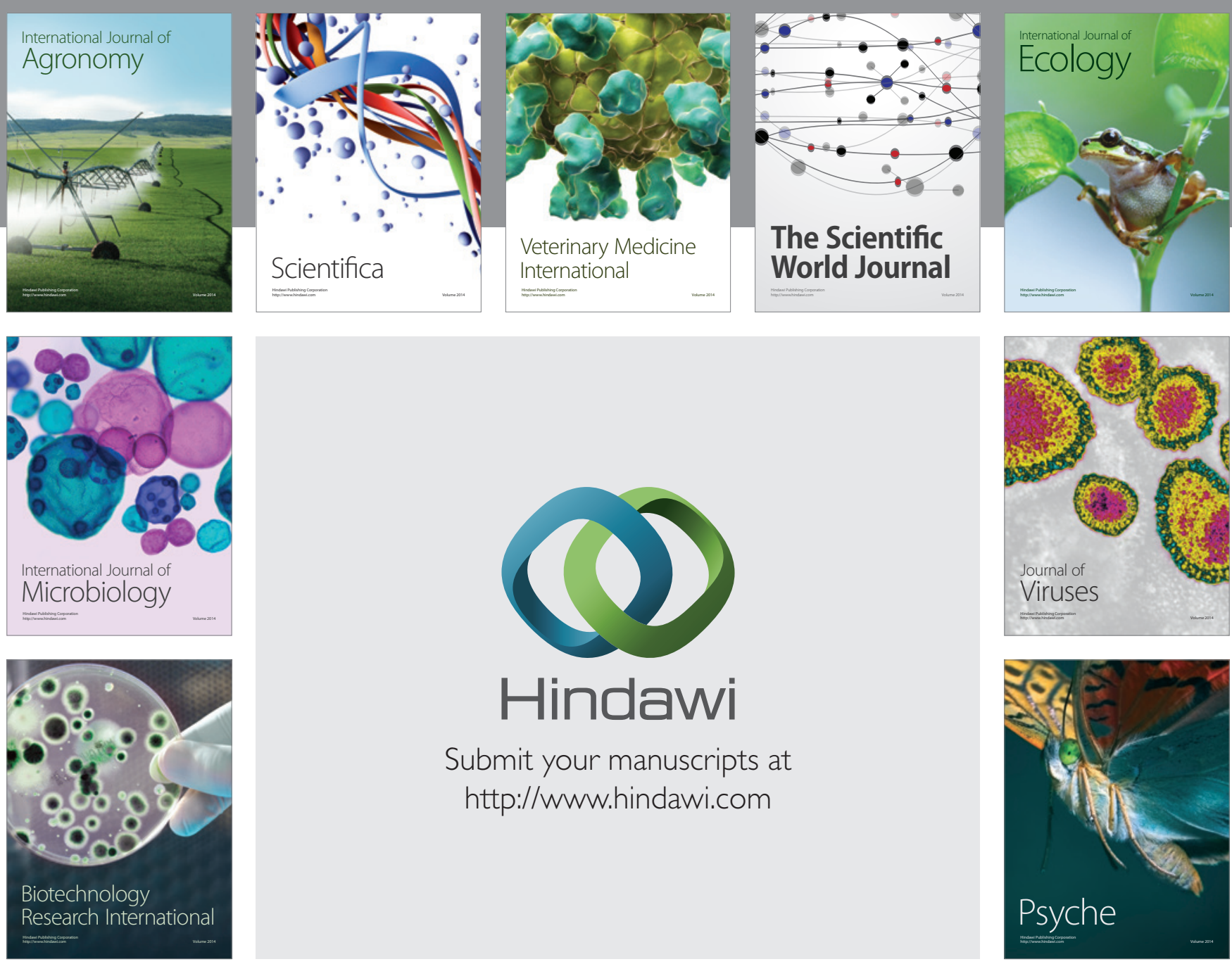

Submit your manuscripts at http://www.hindawi.com
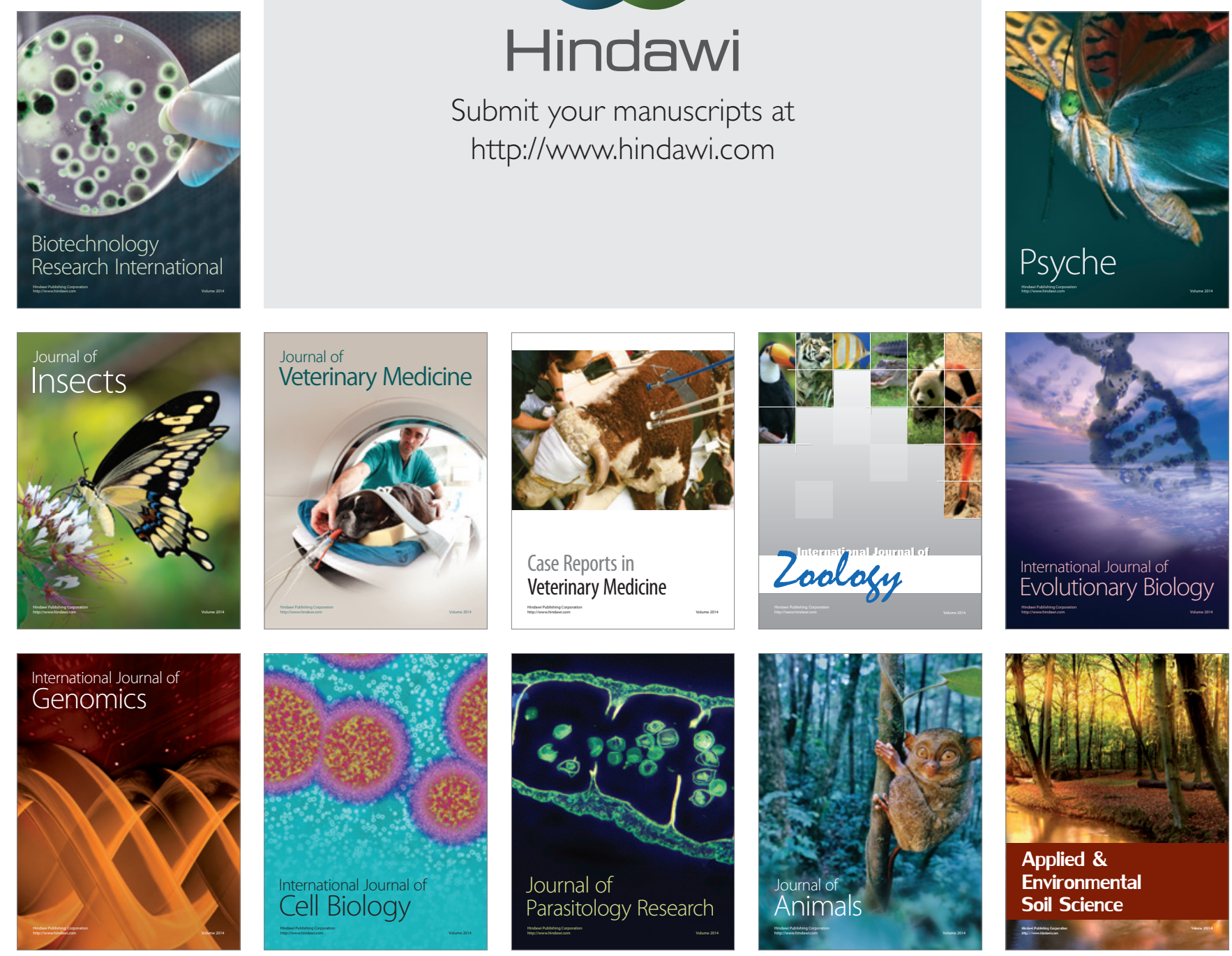